\title{
Bone Mineral Density and Weaning Weight of Piglets from First-Parity Sows Fed Zinc during Gestation and Lactation
}

\section{Claudia Cassimira Silva ${ }^{1}$, Natalia Barros Petroli Utimi ${ }^{1}$, Larissa José Parazzi $^{2}$, Cristiane Soares da Silva Araújoº ${ }^{2}$ Brunna Garcia de Souza Leite $^{1}$, Maitê Vital Mendonça ${ }^{2}$, Yasmin Gonçalves de Almeida Sartore' ${ }^{2}$, Vera Letticie de Azevedo Ruiz², Simone Maria Massami Kitamura Martins $^{1}$, Carlos Alexandre Granghelli ${ }^{1}$ and Lúcio Francelino Araújo ${ }^{1 *}$}

${ }^{1}$ Department of Animal Science, University of Sao Paulo, Brazil

${ }^{2}$ Department of Animal Nutrition and Production, University of Sao Paulo, Brazil

${ }^{3}$ Department of Veterinary Medicine, University of Sao Paulo, Brazil

*Corresponding Author: Lúcio Francelino Araujo, Department of Animal Science, University of São Paulo, Brazil.

\author{
Received: July 21, 2021
}

Published: August 23, 2021

(C) All rights are reserved by Lúcio Francelino Araújo., et al.

\begin{abstract}
This study aimed to evaluate the effects of zinc provided to sows and their progeny on reproductive parameters, litter and nursery piglet's performance, zinc (Zn) concentration in plasma, colostrum and milk, bone densitometry, fecal score and intestinal morphometry in piglets. A total of 18 first-parity sows and their hundred and eighty weaned piglets at 21-d-old, were distributed according to a randomized block experimental design in a $3 \times 3$ factorial arrangement into nine treatments, consisting of the supplementation of $100 \mathrm{mg} \mathrm{Zn/kg} \mathrm{of} \mathrm{three} \mathrm{different} \mathrm{sources} \mathrm{(zinc-glycine} \mathrm{(ZnGly),} \mathrm{zinc} \mathrm{amino} \mathrm{acid} \mathrm{complex} \mathrm{(ZnAA)} \mathrm{or} \mathrm{zinc} \mathrm{oxide} \mathrm{(ZnO)} \mathrm{in} \mathrm{the} \mathrm{maternal}$ (gestation and lactation) and in the nursery diets. Data were analyzed by MIXED procedures of SAS, and means were compared by the test of Tukey-Kramer. Significance was assessed at $\mathrm{P} \leq 0.05$ and trends were discussed at $\mathrm{P}>0.05 \leq 0.1$. Pregnant sows fed $\mathrm{ZnO}$ had greater total feed intake than those fed organic $\mathrm{Zn}$, and lower body weight loss $(\mathrm{P}<0.05)$. Also, piglets from sows fed $\mathrm{ZnO}$ had greater ADG ( $\mathrm{P}=0.05)$ compared with other treatments. Colostrum and milk Zn concentration were not affected by diet $(\mathrm{P}>0.05)$. Plasma $\mathrm{Zn}$ concentration at $21 \mathrm{~d}$ of lactation in the ZnAA sows were higher than those fed with ZnGly, but it was similar to ZnO (P < 0.05). At 21-d-old, ZnO sows had heavier piglets $(\mathrm{P}<0.05)$ compared to ZnGly sows, but were similar to ZnAA sows. Also, the piglets from sows fed ZnAA had higher ( $<$ < 0.05) BMD than those from ZnO sows, but it was similar to sows fed ZnGly the ZnO + ZnGly piglets weaned showed $28.2 \%$ of incidence of pasty feces than those in the ZnGly + ZnAA (18.2\%) and ZnGly + ZnGly (16.4\%) groups, but it similar to the other groups. At 70-d-old, the lowest villus height $(\mathrm{P}<0.05)$ was measured in the duodenum of ZnAA + ZnGly piglets compared to other treatments. The larger CD was observed when the piglets received $\mathrm{ZnO}$ and $\mathrm{ZnGly}(\mathrm{P}<0.05)$, regardless $\mathrm{Zn}$ source from sow. These data suggest that sows fed diets supplemented with $\mathrm{ZnO}$ during gestation may be able to increase total feed intake of sow and piglets weaning weight and reduce body weight loss sow. However, in the nursery pig there seems to be very little difference among zinc source on intestinal morphometry, performance and zinc plasma concentration.
\end{abstract}

Keywords: Colostrum; Diarrhea; Immunity; Nursery; Organic Trace Minerals

\section{Introduction}

Pig production has become increasingly efficient due to advances in genetic breeding, nutrition, the use of reproductive biotech- nologies, among other factors. This improvement made the hyperprolific swine females be able to produce a high number of live-born piglets, and little is known about the mineral requirements of reproductive females during gestation and lactation periods. 
Zinc is involved in the metabolism of proteins, carbohydrates, nucleotides and vitamin $\mathrm{A}$, and it is required for calcium deposition in the bones, for immune system development, and the synthesis of hormones, insulin and adrenal corticosteroids [1]. Besides, it acts as a cofactor in several enzyme systems, and it is also a component of several enzymes [2], that are essential for cellular functions, and the deficiency of zinc iron and copper is a serious problem for infants $[3,4]$.

The results of some researcher have shown contradictory effects, it is yet not clear whether the different $\mathrm{Zn}$ sources provided for sows during pregnant and lactating could help in the development from newborn piglets until wean and, whether would be interesting an additional in the diet of nursery piglets.

The delivery of an adequate supply of trace elements from the pregnant sow to the fetus is fundamental for growth and subsequently for the survival of the postnatal pig [5]. The minerals in sow milk are especially necessary for breastfeeding newborns, who can only get minerals from milk [6]. Zn accumulates in the liver of fetus from the last trimester of gestation, which functions as the primary source of nutrients for piglet [7].

Depending on its dose and chemical form, Zn can act as a nutrient, antioxidant or may even become toxic. The nutritional requirement of inorganic $\mathrm{Zn}$ for reproductive females is $119.7 \mathrm{mg} / \mathrm{kg}$ and organic $53.9 \mathrm{mg} / \mathrm{kg}$ [8]. Differences may occur between organic and inorganic Zn source in terms of their bioavailability [9]. Also, nursery piglets the requirement is 80 to $100 \mathrm{mg} / \mathrm{kg}[10,11]$ and $123 \mathrm{mg} / \mathrm{kg}$ [8]. Other researcher reported that a $\mathrm{Zn}$ concentration between 50 and $60 \mathrm{mg} / \mathrm{kg}$ feed would meet the requirements in cereal-based diets for young pigs [12]. In corn, soybean, whey-based diets $75 \mathrm{mg} \mathrm{Zn}$ per $\mathrm{kg}$ feed were considered to be sufficient [13].

Among the inorganic sources, $\mathrm{ZnO}$ is the most commonly used in animal nutrition. However, due to its low bioavailability and to the possible interactions, the inclusion of inorganic Zn concentration is usually higher than those recommended, which can result in environmental pollution [14].

In contrast, organic trace minerals showed higher absorption by the animal, as they are absorbed through the pathways of organic molecules to which they are associated $[15,16]$.

\section{Aim of the Study}

Thus, the present study aimed to investigate the effects of zinc provided to sows and their progeny on reproductive parameters, litter and nursery piglets' performance, zinc concentration in plasma, colostrum and milk, bone densitometry, fecal score and intestinal morphometry in piglets.

\section{Materials and Methods}

The trial was performed in the Swine Research Laboratory of the School of Veterinary Medicine and Animal Science, University of Sao Paulo. The basal diets were based on corn and soybean meal. No zinc was supplemented in the basal diets. The ingredient and nutritional composition of the basal gestation, lactation and nursery diets is shown in table 1.

All the animals were supplemented with $100 \mathrm{mg} / \mathrm{kg}$ of one of three Zn sources (ZnGly, ZnAA or ZnO). The ZnGly (B-Traxim ${ }^{\circledR} 2 \mathrm{C}$ Zn, Pancosma, Geneva, Switzerland) contained $26 \%$ of $Z n$ chelated with glycine, the Zn amino acid complex (Availa ${ }^{\circledR} \mathrm{Zn}$, Zinpro Corporation, Eden Prairie, MN, USA) contained $10 \%$ of $\mathrm{Zn}$ chelated with methionine, and the $\mathrm{ZnO}$ product (Óxido de zinco $\mathrm{CR}^{\circledR}$, Sul Óxidos, Forquilhinha, Brazil) contained $80 \% \mathrm{Zn}$.

\begin{tabular}{|c|c|c|c|c|c|}
\hline \multirow[b]{2}{*}{ Ingredients1 } & \multirow[b]{2}{*}{$\begin{array}{l}\text { Gesta- } \\
\text { tion }\end{array}$} & \multirow{2}{*}{$\begin{array}{c}\text { Lactation } \\
\text { Pre- } \\
\text { starter } \\
\end{array}$} & \multicolumn{3}{|c|}{ Nursery } \\
\hline & & & $\begin{array}{c}\text { Starter } \\
1\end{array}$ & $\begin{array}{c}\text { Starter } \\
2\end{array}$ & \\
\hline Corn & 76 & 60 & 36.8 & 47.8 & 59.2 \\
\hline $\begin{array}{l}\text { Soybean meal } \\
(46 \% \mathrm{CP})\end{array}$ & 20 & 28.4 & 20.5 & 25.0 & 35.0 \\
\hline Sugar & - & 4 & - & - & - \\
\hline Soybean Oil & - & 3.6 & - & - & - \\
\hline $\begin{array}{l}\text { Pregnancy pre- } \\
\text { mix }^{1}\end{array}$ & 4 & - & & & \\
\hline Lactation premix ${ }^{2}$ & - & 4 & - & - & - \\
\hline $\begin{array}{l}\text { Pre-starter pre- } \\
\mathrm{mix}^{3}\end{array}$ & - & - & 40.0 & - & - \\
\hline Starter 1 premix $^{4}$ & - & - & - & 25.0 & - \\
\hline Starter 2 premix ${ }^{5}$ & - & - & - & - & 2.5 \\
\hline Energy premix ${ }^{6}$ & - & - & 2.5 & 2.0 & 0.3 \\
\hline Flavor $^{7}$ & - & - & 0.2 & 0.2 & 3.0 \\
\hline \multicolumn{6}{|c|}{ Calculated composition } \\
\hline $\mathrm{ME}, \mathrm{MJ} / \mathrm{kg}$ & 13.39 & 14.15 & 14.28 & 14.10 & 13.71 \\
\hline $\mathrm{CP}(\%)$ & 14.69 & 18.14 & 20.84 & 20.07 & 21.42 \\
\hline Crude fiber (\%) & 2.98 & 3.08 & 2.39 & 2.66 & 3.40 \\
\hline Ash (\%) & 5.53 & 5.74 & 5.40 & 5.18 & 5.92 \\
\hline Calcium (\%) & 0.78 & 0.78 & 0.72 & 0.61 & 0.82 \\
\hline Total phosphorus & 0.53 & 0.53 & 0.54 & 0.56 & 0.57 \\
\hline $\begin{array}{l}\text { Digestible lysine } \\
(\%)\end{array}$ & 0.65 & 1 & 1.34 & 1.27 & 1.05 \\
\hline Total Lactose (\%) & - & - & 10.00 & 5.00 & 0 \\
\hline $\mathrm{Zn}(\mathrm{mg} / \mathrm{kg})^{8}$ & 100 & 100 & 100 & 100 & 100 \\
\hline
\end{tabular}

Table 1: Composition of gestation, lactation and nursery diets (\%,as-fed basis). 
${ }^{1}$ Pregnancy feed unit supplies (per kg of product) folic acid $36 \mathrm{mg}$, pantothenic acid $325 \mathrm{mg}$, biotin $2.5 \mathrm{mg}$, calcium $170 \mathrm{~g}$, cobalt $4 \mathrm{mg}$, copper $375 \mathrm{mg}$, choline $12,000 \mathrm{mg}$, iron $625 \mathrm{mg}$, phosphorus 50 $\mathrm{g}$, phytase 12,500 FTU, iodine $35 \mathrm{mg}$, manganese $1,000 \mathrm{mg}$, niacin $487.5 \mathrm{mg}$, selenium $11.16 \mathrm{mg}$, sodium $50 \mathrm{~g}$, vitamin A 375,000 IU, vitamin B1 $50 \mathrm{mg}$, vitamin B12 $620 \mathrm{mcg}$, vitamin B2 $96 \mathrm{mg}$, vitamin B6 50 mg, vitamin D3 93,750 IU, vitamin E 825 IU, vitamin K3 82.5 $\mathrm{mg}$.

${ }^{2}$ Lactation feed unit supplies (per kg of product) folic acid $36 \mathrm{mg}$, pantothenic acid $325 \mathrm{mg}$, biotin $2.92 \mathrm{mg}$, calcium $175 \mathrm{~g}$, cobalt 4 $\mathrm{mg}$, copper $450 \mathrm{mg}$, choline 12,000 mg, iron $625 \mathrm{mg}$, phosphorus $45 \mathrm{~g}$, phytase $12,500 \mathrm{FTU}$, iodine $35 \mathrm{mg}$, manganese $1,000 \mathrm{mg}$, niacin $487.5 \mathrm{mg}$, selenium $11.16 \mathrm{mg}$, sodium $45 \mathrm{~g}$, vitamin A 375,000 IU, vitamin B1 50 mg, vitamin B12 $620 \mu \mathrm{g}$, vitamin B2 96 mg, vitamin B6 50 mg, vitamin D3 93,750 IU, vitamin E 825 IU, vitamin K3 $82.5 \mathrm{mg}$.

${ }^{3}$ Pre-starter feed unit supplies (per kg of product) folic acid $2.25 \mathrm{mg}$; fumaric acid $20 \mathrm{~g}$; pantothenic acid $78 \mathrm{mg}$; biotin $1.13 \mathrm{mg}$; calcium $16 \mathrm{~g}$; copper $500 \mathrm{mg}$; choline 2,900 mg; iron $225 \mathrm{mg}$; phosphorus $8,000 \mathrm{mg}$; phytase 1,250 FTU, iodine $2 \mathrm{mg}$; lysine $18 \mathrm{~g}$; manganese $75 \mathrm{mg}$; methionine 7,000 mg; niacin $112 \mathrm{mg}$; selenium $1.35 \mathrm{mg}$; sodium 7,500 $\mathrm{mg}$; threonine $10.20 \mathrm{~g}$; tryptophan 2,300 $\mathrm{mg}$; valine

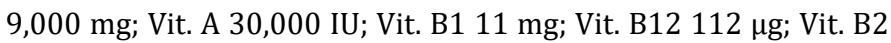
22 mg; Vit. B6 13 mg; Vit. D3 8,000 IU; Vit. E 335 IU; Vit. K 25 mg.

${ }^{4}$ Starter 1 feed unit supplies (per kg of product) Folic acid $3 \mathrm{mg}$; fumaric acid $24 \mathrm{~g}$; pantothenic acid $100 \mathrm{mg}$; biotin $1.23 \mathrm{mg}$; calcium 23.50 g; copper $800 \mathrm{mg}$; choline 3,600 mg; iron $360 \mathrm{mg}$; phosphorus $8,000 \mathrm{mg}$; phytase 2,000 FTU, iodine $2 \mathrm{mg}$; lysine $18 \mathrm{~g}$; manganese $75 \mathrm{mg}$; methionine 7,000 mg; niacin $112 \mathrm{mg}$; selenium 1.35 $\mathrm{mg}$; sodium 7,500 mg; threonine $10.20 \mathrm{~g}$; tryptophan 2,300 mg; valine 9,000 mg; Vit. A 30,000 IU; Vit. B1 11 mg; Vit. B12 $112 \mu \mathrm{g}$; Vit. B2 22 mg; Vit. B6 13 mg; Vit. D3 8,000 IU; Vit. E 335 IU; Vit. K $25 \mathrm{mg}$.

${ }^{5}$ Starter 2 feed unit supplies (per kg of product) Folic acid 12 mg; pantothenic acid $320 \mathrm{mg}$; biotin $2 \mathrm{mg}$; calcium $135 \mathrm{~g}$; copper 2,500 mg; choline 4,000 mg; phosphorus 3,900 mg; phytase 10,000 FTU, iodine $20 \mathrm{mg}$; lysine $34 \mathrm{~g}$; manganese $1,400 \mathrm{mg}$; methionine 1,200 $\mathrm{mg}$; niacin $600 \mathrm{mg}$; selenium $6 \mathrm{mg}$; sodium 3,560 mg; threonine 17 g; Vit. A 240,000 IU; Vit. B1 40 mg; Vit. B12 400 нg; Vit. B2 120 mg; Vit. B6 60 mg; Vit. D3 40,000 IU; Vit. E 900 IU; Vit. K 60 mg.

${ }^{6}$ Energy feed unit supplies (per kg of product) Beta-mananase 2,003.4 u; calcium 5,000 mg; phosphorus 3,000; lysine 8,400 mg; methionine $2,500 \mathrm{mg}$.
${ }^{7}$ Flavor feed unit supplies (per kg of product) Neoesperidine 1,200 mg; Saccharin sodic 58,2 g; vanilla aroma $25 \mathrm{~g}$.

${ }^{8} \mathrm{Zinc} 100 \mathrm{mg}$ de $\mathrm{Zn} / \mathrm{kg}$ of diet in the ZnGly product (B-Traxim ${ }^{\circledR} 2 \mathrm{C}$ Zn, Pancosma, Geneva, Switzerland) contained $26 \%$ of Zn chelated with glycine, the ZnAA product (Availa ${ }^{\circledR}$ Zn, Zinpro, Minnesota, USA) contained $10 \%$ of $\mathrm{Zn}$ chelated with methionine, and the $\mathrm{ZnO}$ product (Óxido de zinco $\mathrm{CR}^{\circledR}$, Sul Óxidos, Forquilhinha, Brazil) contained $80 \% \mathrm{Zn}$.

\section{Gestation and lactation}

Eighteen commercial hybrid gilts (C23, Agroceres PIC, Rio Claro, Brazil) were individually penned and used in a complete randomized design experiment. Six gilts per treatment received one of three Zn sources (ZnGly, ZnAA and ZnO).

After AI and during the first week of pregnancy, gilts of groups were fed twice a day, totaling $1.5 \mathrm{~kg} / \mathrm{d}$ of a diet containing $14.7 \%$ $\mathrm{CP}$ and $13.39 \mathrm{MJ} / \mathrm{kg}$ of ME. From 7 to $80 \mathrm{~d}$ of pregnancy, the amount of feed was adjusted according to body condition score (BCS), it was divided into 5 classes: 1 = very thin, 2 = thin, $3=$ normal, $4=$ fat, and $5=$ very fat. Females that showed BCS equal to or less than 2 received more feed to reach score 3.

From $80 \mathrm{~d}$ of pregnancy to farrowing, the females received 3.3 $\mathrm{kg} / \mathrm{d}$ gestation diet. At $3 \mathrm{~d}$ before farrowing, gilts were fed $1.5 \mathrm{~kg} / \mathrm{d}$ of their treatment feed and an additional $0.5 \mathrm{~kg} / \mathrm{d}$ of wheat bran. At the first $24 \mathrm{~h}$ after farrowing, sows were fed $1.5 \mathrm{~kg} / \mathrm{sow}$ of lactation feed containing $18.14 \% \mathrm{CP}$ and $14.15 \mathrm{MJ} / \mathrm{kg}$ of ME, and this amount was gradually increased until $120 \mathrm{~h}$. Afterward, sows were fed lactation diets until weaning to approximate ad libitum intake. Uneaten feed was removed and weighed daily before the morning feeding.

At the moment of $\mathrm{AI}$, gilts were in fifth estrus, average body weight and back fat (136.93 $\pm 6.63 \mathrm{~kg}$ and $11.62 \pm 1.70 \mathrm{~mm}$ ), making up a homogenous sample. Gilts were checked for standing estrus by placing an intact boar into the pen for $15 \mathrm{~min} / \mathrm{d}$. Gilts were inseminated at intervals of 12 hours until the end of estrus with pooled semen.

Approximately 35d after AI, pregnancy was detected using a real-time ultrasound (Scanner 100, 5 MHz transducer, Pie Medical, Maastricht, the Netherlands). At approximately $107 \mathrm{~d}$ of pregnancy, gilts were moved into individual crates in rooms with 8 farrowing crates. Routine procedures (teeth clipping, tail docking, ear notch- 
ing, and iron injection) were conducted $2 \mathrm{~d}$ after farrowing, and no creep feed was offered. Within 36 hours of farrowing, attempts were made via cross-fostering within treatment to adjust each litter to approximately 12 piglets per sow. The pigs were weaned at an average age of 21- $d$ and all piglets were weaned on the same day regardless of the farrowing date.

Sows body weight was measured at 45, 65, 106 days of gestation, $1 \mathrm{~d}$ after farrowing and 21 days of lactation. Back fat (BF) was measured by ultrasound ( $5 \mathrm{MHz}$ transducer) at $\mathrm{P} 2$ position in the similar days of body weight. The blood of six sows per treatment was collected from the jugular vein at $15 \mathrm{~d}$ before AI, 45, 65, 106 days of gestation, and 21 days of lactation for the analysis of plasma Zn concentration. Also, it was evaluated Zn concentration in colostrum (day of farrowing) and milk (21 days of lactation) by atomic absorption spectrophotometry [17].

\section{Nursery}

One hundred and eighty piglets were supplemented same $\mathrm{Zn}$ sources in diet during nursery period, compound a $3 \times 3$ treatment factorial design, totaling nine treatments with five replicates (pens) of four pigs (two males and two females) each.

The nursery basal diets (pre-starter, from 21 to 35 days; starter 1 , from 36 to 49 days, and starter 2, from 50 to 70 days of age) were formulated according to the nutritional recommendations of the [11].

Piglets were weighed at 21,35, 49 and 70 days of age. Average daily feed intake, Average daily gain, and feed gain ratio (g feed intake/g weight gain) were calculated for the periods of 21 to 35 days, 36 to 49 days and 50 to 70 days of age.

\section{Tissue and bone collection and analyses}

The blood of five piglets per treatment was collected from the cranial vena cava, at 21 and 70 days of age for the analysis of plasma Zn concentration by atomic absorption spectrophotometry [17]. Piglets were vaccinated at 28 and 42 days of age against Streptococcus suis according to the manufacturer's recommendations. Blood collection was performed at 42 and 70 days of age, for the measurement of vaccine antibodies using ELISA. The blood collected both for $\mathrm{Zn}$ serum and antibody measurements was centrifuged at 3.000 rpm for $15 \mathrm{~min}$, and the serum samples were stored at $-20^{\circ} \mathrm{C}$ in a freezer until analyses.

Four piglets per treatment were euthanized by electronarcosis, followed by bleeding, at 21 and 70 days of age, and their right me- tacarpal bone was collected for bone densitometry analyses. Bone mineral content (BMC) and bone mineral density (BMD) were determined using a dual-emission X-ray densitometer (DXA) (model DPX-1 ALPHA, GE Healthcare Lunar ${ }^{\circledR}$, United Kingdom) coupled with software specially designed for small animals. Bone densitometric readings were performed by scanning and storing the radiographic images in a microcomputer to obtain BMC and BMD values [18].

The duodenum of the same piglets euthanized for bone densitometry analyses was collected to measure villus height, crypt depth, and villus height: crypt depth ratio. The methodology proposed by Pekas [19] was applied. Each collected fragment was washed and fixed in Bouin's solution. After 24 hours, samples were washed in ethyl alcohol at $70^{\circ} \mathrm{C}$ and afterward dehydrated in graded alcohol series. After dehydration, samples were trimmed, cleared in benzol, embedded in paraffin, and sectioned for slide assemble. Slides were stained with Harris' hematoxylin eosin. Villus height and crypt depth were measured under light microscopy using the image analyzer system at $230 \mathrm{x}$ magnitude.

Visual analysis of the feces was carried out daily, with scores ranging from 1 to 3 for each animal: 1 = solid feces (normal); 2 = feces softer than normal (pasty); and 3 =liquid feces (severe diarrhea).

\section{Statistical analysis}

Data collected during gestation and lactation were analyzed by ANOVA appropriate for a completely randomized design using the GLM procedures of SAS [20]. The individual sow was the experimental unit for all data. Data collected during the nursery phases were analyzed using the MIXED procedure of SAS [20] for a randomized block design. The pen of pigs served as the experimental unit for ADFI, FGR, and fecal score. For individual body weight, ADG, Zn serum concentration, bone densitometry, antibody levels and intestinal morphometry, the piglet was considered as experimental unit. Means were compared by the test of Tukey-Kramer. Significance was assessed at $\mathrm{P} \leq 0.05$ and trends were discussed at $\mathrm{P}>0.05 \leq 0.1$. All results were expressed as means.

\section{Results}

\section{Gestation and lactation}

There was no effect of diet on sows' performance ( $P>0.05$ ). Pregnant sows fed $\mathrm{ZnO}$ had greater total feed intake than those fed organic $\mathrm{Zn}(\mathrm{P}<0.05), 259.96 \pm 4.16,253.86 \pm 3.53$ and $249.26 \pm 2.33 \mathrm{~kg}, \mathrm{ZnO}, \mathrm{ZnAA}$ and ZnGly, respectively. Sows ZnAA 
fed had higher body weight loss than those fed $\mathrm{ZnO}(0.46 \pm 0.14$, $0.24 \pm 0.23 \mathrm{~kg} / \mathrm{d})(\mathrm{P}<0.05)$, but it was similar to ZnGly $(0.44 \pm 0.09$ $\mathrm{kg} / \mathrm{d})$.

Litter size and body weight at birth were similar among sows supplemented with organic and inorganic zinc, although there was a tendency $(\mathrm{P}=0.066)$ towards higher body weight at weaning in piglets from sows fed $\mathrm{ZnO}$ (6.45 kg), almost the equivalent of $1 \mathrm{~kg}$ more, compared with organic Zn sows, regardless source (5.63 and $5.47 \mathrm{~kg}$, ZnAA and ZnGly, respectively. Also, piglets from sows fed $\mathrm{ZnO}$ had greater ADG $(\mathrm{P}=0.05)$ than those fed organic $\mathrm{Zn}(0.24$ vs 0.21 and $0.20 \mathrm{~kg} /$ day, ZnO vs ZnAA and ZnGly, respectively).

Colostrum and milk $\mathrm{Zn}$ concentration were not affected by diet ( $\mathrm{P}>0.05$ ). Plasma $\mathrm{Zn}$ concentration at 21 days of lactation in the sows fed ZnAA (1.34 mg/L) were higher than those fed with ZnGly $(1.00 \mathrm{mg} / \mathrm{L})$, but it was similar to $\mathrm{ZnO}(1.22 \mathrm{mg} / \mathrm{L}, \mathrm{P}<0.05)$.

\section{Nursery}

There was no interaction between maternal (gestation and lactation) and nursery diets for any of the analyzed parameters, except for fecal score. The piglets in the $\mathrm{ZnO}+\mathrm{ZnGly}$ group presented higher incidence of pasty feces $(28.2 \%)$ than those in the ZnGly + ZnAA (18.2\%) and ZnGly + ZnGly (16.4\%) groups, whereas the other groups presented intermediate values (Figure 1). Higher incidence of normal feces $(\mathrm{P}<0.05)$ was detected during the periods of 36 to 49 days (76.98\%) and of 50 to 70 days (71.76\%) compared with the period of 21 to 35 days (60\%).
The sow's fed ZnO had heavier piglets at 21-d-old $(\mathrm{P}<0.05)$ compared to females fed ZnGly, but were similar to ZnAA sows. At 49 days of age, there was a tendency $(P=0.068)$ towards higher body weight in the pigs from sow fed $\mathrm{ZnO}$ compared with $\mathrm{ZnAA}$ and ZnGly sows. No effects of Zn sources supplemented in maternal or nursery diets $(\mathrm{P}>0.05)$ were observed on ADG, ADFI and FGR piglets between 21 and 70 days of age (Table 3). Although, there was a trend $(\mathrm{P}=0.073)$ towards greater $\mathrm{ADG}$ in pigs from sow fed $\mathrm{ZnO}$ related to other treatments, in the period of 50 to 70 days. Besides, Also, there was a tendency $(\mathrm{P}=0.071)$ towards better FGR in pigs who received ZnAA in diet compared with ZnGly and ZnO.

Plasma Zn concentration and antibody levels of 70-d-old piglets were not affected by diets $(\mathrm{P}>0.05)$. At 21 days of age, piglets from sows fed ZnAA $\left(0.12 \mathrm{~g} / \mathrm{cm}^{2}\right)$ had higher $(\mathrm{P}<0.05)$ BMD than those from females receiving $\mathrm{ZnO}\left(0.08 \mathrm{~g} / \mathrm{cm}^{2}\right)$, but it was similar to sows fed ZnGly $\left(0.09 \mathrm{~g} / \mathrm{cm}^{2}\right)$. However, at 70 days, there were no difference among treatments ( $\mathrm{P}>0.05$, Table 2$)$. Also, $\mathrm{BMC}$ at 21 and 70 days of age were not affected by $\mathrm{Zn} \operatorname{diet}(\mathrm{P}>0.05$, Table 2$)$.

The piglets from sows fed different Zn sources had similar duodenal morphometry measured in 21-d-old piglets. However, at 70 days of age, the lowest villus height $(P<0.05)$ was measured in the duodenum of piglets of the $\mathrm{ZnAA}+\mathrm{ZnGly}$ group compared to other treatments. Concerning CD, regardless of the source of zinc provided for sows, the larger CD were observed when the piglets received $\mathrm{ZnO}$ and $\mathrm{ZnGly}$ in the diets $(\mathrm{P}<0.05)$. No villus height to crypt depth ratio differences were observed among treatments $(\mathrm{P}>0.05)$. The results are presented in table 2 .

\begin{tabular}{|c|c|c|c|c|c|c|c|c|c|c|c|c|c|}
\hline \multirow{3}{*}{$\begin{array}{c}\text { Item } \\
\mathrm{M} \\
\mathrm{N}\end{array}$} & \multicolumn{9}{|c|}{ Treatment } & \multirow{3}{*}{ SEM } & \multirow{2}{*}{\multicolumn{3}{|c|}{ P-value }} \\
\hline & \multicolumn{3}{|c|}{ ZnO } & \multicolumn{3}{|c|}{ ZnAA } & \multicolumn{3}{|c|}{ ZnGly } & & & & \\
\hline & ZnO & ZnAA & ZnGly & ZnO & ZnAA & ZnGly & ZnO & ZnAA & ZnGly & & $\mathbf{M}$ & $\mathbf{N}$ & $\mathbf{M} * \mathbf{N}$ \\
\hline \multicolumn{14}{|c|}{ Zn plasma concentration (mg/L) } \\
\hline 70 & 1.54 & 1.47 & 1.42 & 1.34 & 1.32 & 1.45 & 1.55 & 1.48 & 1.50 & 0.029 & 0.137 & 0.735 & 0.729 \\
\hline \multicolumn{14}{|c|}{ Bone densitometry } \\
\hline BMC & 1.98 & 1.65 & 1.86 & 1.84 & 1.72 & 1.72 & 2.01 & 1.58 & 1.65 & 0.055 & 0.813 & 0.115 & 0.865 \\
\hline BMD & 0.25 & 0.23 & 0.24 & 0.26 & 0.24 & 0.23 & 0.28 & 0.26 & 0.23 & 0.006 & 0.599 & 0.178 & 0.722 \\
\hline \multicolumn{14}{|c|}{ Duodenal Morphometry $(\mu \mathrm{m})$} \\
\hline VH & $544.63^{\mathrm{a}}$ & $566.49^{\mathrm{a}}$ & $579.23^{a}$ & $577.12^{\mathrm{a}}$ & $573.46^{\mathrm{a}}$ & $521.94^{\mathrm{b}}$ & $550.60^{\mathrm{a}}$ & $592.77^{\mathrm{a}}$ & $579.36^{\mathrm{a}}$ & 4.079 & 0.283 & 0.146 & 0.003 \\
\hline $\mathrm{CD}$ & $326.00^{\mathrm{ab}}$ & $288.73^{\mathrm{b}}$ & $363.72^{\mathrm{a}}$ & $377.08^{\mathrm{a}}$ & $327.77^{\mathrm{b}}$ & $342.60^{\mathrm{ab}}$ & $349.34^{\mathrm{b}}$ & $318.96^{\mathrm{b}}$ & $408.71^{\mathrm{a}}$ & 3.981 & 0.003 & $<.0001$ & 0.002 \\
\hline VH:CD & 1.82 & 2.23 & 1.71 & 1.66 & 1.90 & 1.63 & 1.73 & 2.16 & 1.55 & 6.110 & 0.278 & 0.266 & 0.242 \\
\hline
\end{tabular}

Table 2: Zinc plasma concentration, bone densitometry and intestinal morphometry parameters measured on 70-d-old piglets.

$\mathrm{M}$ - maternal diet; $\mathrm{N}$ - nursery diet, $\mathrm{M} * \mathrm{~N}$ - interaction between maternal and nursery diet Zn supplementation sources; BMC - bone mineral content (g); BMD - bone mineral density $\left(\mathrm{g} / \mathrm{cm}^{2}\right)$; VH - villus height; CD - crypt depth; VH:CD - villus height to crypt depth ratio.

Means followed by different superscripts in the same row are statistically different by the test of Tukey-Kramer $(\mathrm{p}<0.05)$. 


\begin{tabular}{|c|c|c|c|c|c|c|c|c|c|c|c|c|c|}
\hline \multirow{3}{*}{$\begin{array}{c}\text { Item } \\
\mathbf{M} \\
\mathrm{N}\end{array}$} & \multicolumn{9}{|c|}{ Treatment } & \multirow{3}{*}{ SEM } & \multirow{2}{*}{\multicolumn{3}{|c|}{ P-value }} \\
\hline & \multicolumn{3}{|c|}{ ZnO } & \multicolumn{3}{|c|}{ ZnAA } & \multicolumn{3}{|c|}{ ZnGly } & & & & \\
\hline & Zno & ZnAA & ZnGly & Zno & ZnAA & ZnGly & Zno & ZnAA & ZnGly & & $\mathbf{M}$ & $\mathbf{N}$ & $\mathbf{M} * \mathbf{N}$ \\
\hline \multicolumn{14}{|c|}{ BW (kg) } \\
\hline 21 & 6.53 & 6.57 & 6.50 & 6.34 & 6.29 & 6.29 & 5.72 & 5.69 & 5.65 & 0.110 & 0.007 & 0.979 & 1.000 \\
\hline 35 & 9.57 & 9.52 & 9.36 & 9.14 & 9.23 & 9.10 & 8.93 & 8.48 & 8.54 & 0.139 & 0.299 & 0.396 & 0.966 \\
\hline 49 & 17.13 & 17.05 & 17.26 & 16.85 & 16.54 & 16.45 & 16.30 & 15.85 & 15.69 & 0.220 & 0.068 & 0.824 & 0.978 \\
\hline 70 & 33.23 & 31.98 & 31.98 & 32.15 & 32.00 & 31.74 & 32.09 & 30.48 & 30.63 & 0.338 & 0.111 & 0.841 & 0.989 \\
\hline \multicolumn{14}{|c|}{$\mathrm{ADG}(\mathrm{Kg} / \mathrm{d})$} \\
\hline $21-35$ & 0.22 & 0.21 & 0.20 & 0.20 & 0.21 & 0.20 & 0.23 & 0.20 & 0.21 & 0.006 & 0.479 & 0.664 & 0.635 \\
\hline $36-49$ & 0.54 & 0.54 & 0.56 & 0.55 & 0.52 & 0.53 & 0.53 & 0.53 & 0.51 & 0.009 & 0.452 & 0.805 & 0.823 \\
\hline $50-70$ & 0.77 & 0.71 & 0.70 & 0.73 & 0.74 & 0.71 & 0.75 & 0.70 & 0.71 & 0.008 & 0.898 & 0.073 & 0.701 \\
\hline $21-70$ & 0.54 & 0.52 & 0.52 & 0.53 & 0.52 & 0.52 & 0.54 & 0.50 & 0.51 & 0.006 & 0.779 & 0.225 & 0.929 \\
\hline \multicolumn{14}{|c|}{ ADFI $(\mathrm{Kg} / \mathrm{d})$} \\
\hline $21-35$ & 0.25 & 0.24 & 0.24 & 0.21 & 0.23 & 0.23 & 0.22 & 0.23 & 0.21 & 0.005 & 0.751 & 0.489 & 0.921 \\
\hline $36-49$ & 0.74 & 0.74 & 0.78 & 0.78 & 0.75 & 0.75 & 0.74 & 0.69 & 0.71 & 0.012 & 0.099 & 0.307 & 0.822 \\
\hline $50-70$ & 1.30 & 1.15 & 1.22 & 1.27 & 1.22 & 1.21 & 1.22 & 1.14 & 1.25 & 0.018 & 0.448 & 0.107 & 0.670 \\
\hline $21-70$ & 0.76 & 0.71 & 0.75 & 0.75 & 0.73 & 0.73 & 0.73 & 0.68 & 0.72 & 0.011 & 0.192 & 0.084 & 0.968 \\
\hline \multicolumn{14}{|l|}{ FGR } \\
\hline $21-35$ & 1.15 & 1.15 & 1.19 & 1.09 & 1.12 & 1.17 & 0.98 & 1.21 & 1.06 & 0.031 & 0.286 & 0.680 & 0.463 \\
\hline $36-49$ & 1.44 & 1.38 & 1.46 & 1.42 & 1.43 & 1.43 & 1.41 & 1.31 & 1.40 & 0.010 & 0.175 & 0.130 & 0.750 \\
\hline $50-70$ & 1.70 & 1.61 & 1.75 & 1.74 & 1.65 & 1.72 & 1.63 & 1.64 & 1.77 & 0.021 & 0.729 & 0.071 & 0.188 \\
\hline $21-70$ & 1.55 & 1.48 & 1.57 & 1.57 & 1.52 & 1.60 & 1.52 & 1.48 & 1.57 & 0.016 & 0.378 & 0.170 & 0.760 \\
\hline
\end{tabular}

Table 3: Growth performance of nursery pigs supplemented Zn sources.

M - maternal diet; N- nursery diet, M* L - interaction between maternal and nursery diet Zn supplementation sources; BW - body weight; ADG - average daily gain; ADFI - daily feed intake; FGR - feed gain ratio.

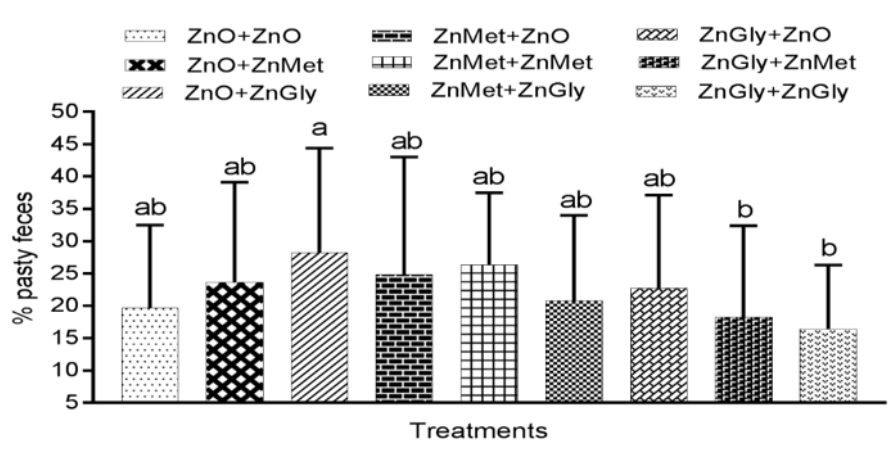

Figure 1: Effect of the supplementation of Zn sources in the maternal and nursery diets on the incidence of pasty feces.

Different superscripts indicate statistical differences by the test of Tukey-Kramer $(\mathrm{p}<0.05)$.

\section{Discussion}

\section{Gestation and lactation}

Zinc is a component of many metalloenzymes, including DNA and RNA synthases and transferases, and many digestive enzymes, and also is associated with the hormone insulin [21]. Thus, the nutrition of sow during gestation and lactation is vital because it should provide the necessary nutrients to support the growth and development of the fetus and piglets [4]. The minerals in sow milk are especially necessary for breastfeeding newborns, who can only get minerals from milk [6].

Current recommendations for $\mathrm{Zn}$ in diets for sows during gestation and lactation are $100 \mathrm{mg} / \mathrm{kg}$ feed and take into account some safety margins due to possible interactions of $\mathrm{Zn}$ with phytate [22], calcium or other factors [11] (NRC, 2012). Besides, differences in bioavailability may occur between organic and inorganic Zn source [9]. 
We observed no effect of $\mathrm{Zn}$ provided to sow diet on sow weight, back fat. Our data agree with those of other researchers [4,23]. Although there was an increase in ADFI during gestation and lower body weight loss for sows fed $\mathrm{ZnO}$, these results were dissimilar to those reported by Payne., et al. [23]. We have no explanations for this result. The sows were randomly allocated in treatments, and the sow was similar body weight and back fat before of AI, so it is not clear how $\mathrm{ZnO}$ could have increased the ADFI gestation, we believe that this higher feed intake could have helped in reduced body weight loss.

The litter size and pig birth weight also were not affected by $\mathrm{Zn}$. These results support previous studies reporting no effect on litter size and pig birth weight of sows fed diets supplemented with $100 \mathrm{mg} / \mathrm{kg} \mathrm{ZnAA}$ or ZnSO4 during gestation and lactation [23], 120 $\mathrm{mg} / \mathrm{kg}$ of $\mathrm{ZnO}$ or $250 \mathrm{mg} / \mathrm{kg} \mathrm{ZnAA}$ provided for sows during the last trimester of gestation [4].

On the other hand, we observed that the pig weaning weight tended to be higher sows fed $\mathrm{ZnO}$, as well as ADG during lactation was higher in the piglets from sows fed $\mathrm{ZnO}$. Our results were dissimilar to those observed by other authors [4,23-25] which it no found differences. Also, disagree with Grela., et al. [26], once these researchers reported significant differences in the body weight of piglets on days 21, with the addition of microbial phytase in 500 FTU/kg diet of sows.

Numerically, the total pigs born and born alive were higher sows fed ZnO. Similarly, Payne., et al., [23] observed no effect of an additional $100 \mathrm{mg} / \mathrm{kg} \mathrm{Zn}$ from ZnAA or ZnSO4 on litter performance, and it the same result was reported by Caine., et al. [4], with supplementation of $250 \mathrm{mg} / \mathrm{kg} \mathrm{ZnAA}$. In contrast, Grela., et al. [26] reported a markedly higher number of liveborn with the addition of microbial phytase in $500 \mathrm{FTU} / \mathrm{kg}$ diet of sows, showing that the use of phytase increase the digestibility of some nutrients and can improve the growing pigs.

The plasma $\mathrm{Zn}$ concentration during gestation, colostrum, and milk was not affected by $\mathrm{Zn}$, however, at 21 days of lactation higher concentrations plasma were observed in sows fed ZnO (1.22 mg/ $\mathrm{kg}$ ) and ZnAA (1.34 mg/kg). In the current study, the highest $\mathrm{Zn}$ concentration in colostrum was observed $17.45 \mathrm{mg} / \mathrm{kg} \mathrm{ZnGly}$, following by $13.15 \mathrm{mg} / \mathrm{kg} \mathrm{ZnO}$ and $12.14 \mathrm{mg} / \mathrm{kg} \mathrm{ZnAA}$. These results were similar to other studies that also obtained high Zn concentration of $15.7 \mathrm{mg} / \mathrm{kg}$ [27], $16.8 \mathrm{mg} / \mathrm{kg}$ without phytase and $24.2 \mathrm{mg} /$ $\mathrm{kg}$ with microbial phytase [26], $15.8 \mathrm{mg} / \mathrm{kg}$ in primiparous, but in sows of 8 parity was observed concentration of $18.2 \mathrm{mg} / \mathrm{kg}$ [25] (Davin., et al. 2015) and $16.18 \mathrm{mg} / \mathrm{kg}$ [28].

Our results for the $\mathrm{Zn}$ concentration in milk at 21-d-old were lower than in the colostrum $(8.29,9.91$ and $9.99 \mathrm{mg} / \mathrm{kg} \mathrm{ZnGly,} \mathrm{ZnO}$ and ZnAA, respectively). Results similar also were observed by other researchers $6.14 \mathrm{mg} / \mathrm{kg}$ [27], $15.7 \mathrm{mg} / \mathrm{kg}$ without phytase [26], $6.22 \mathrm{mg} / \mathrm{kg}$ [25], $5 \mathrm{mg} / \mathrm{kg}$ [28], however with the supplementation of microbial phytase, this concentration was higher than in the colostrum $27.9 \mathrm{mg} / \mathrm{kg} \mathrm{Zn} \mathrm{[26].}$

These our results suggest that sows fed $\mathrm{ZnO}$ made more efficient use of nutrient than sows fed the other sources. Zinc concentration in milk is higher than in serum suggesting that the mammary gland provides active transport and regulation mechanisms for some trace elements $[25,29]$.

Besides, Davin., et al. [25] reported that the concentration of zinc in sow milk was not influenced by the concentration of $\mathrm{Zn}$ in sow feed. It would be difficult to increase the concentration of $\mathrm{Zn}$ in the sow milk by feeding sows a high $\mathrm{Zn}$ diet. However, the organic sources of $\mathrm{Zn}$ due to raising bioavailability could be better utilized by sows, without the need to supply high concentration in the diet.

\section{Nursery}

The dietary supplementation of different $\mathrm{Zn}$ in the maternal and nursery diets did not influence piglet performance. These results agree with some authors [23,30,31] who did not verify any effect of the supplementation of organic Zn sources (100 to 120 $\mathrm{mg} / \mathrm{kg}$ ) in the maternal diet on the performance of nursery piglets.

On the other hand, Case and Carlson [32] observed better performances in nursery piglets fed $500 \mathrm{mg} / \mathrm{kg}$ of a Zn-polysaccharide complex compared with $\mathrm{ZnO}$ (150 mg/kg) and a ZnAA (500 mg/ $\mathrm{kg}$ ). The performance improvement obtained with the supply of organic Zn sources seems to related to $\mathrm{Zn}$ plasma concentration higher than $2.5 \mathrm{mg} / \mathrm{L}$ [33] which is higher than that considered normal for young pigs, of 0.5-1.5 mg/L, according to Kaneko [34]. The raise $\mathrm{Zn}$ plasma concentration above this threshold was obtained with dietary Zn concentration higher than $1000 \mathrm{mg} / \mathrm{kg}$ [35]; however, only $100 \mathrm{mg} / \mathrm{kg}$ were fed in the present study and the $\mathrm{Zn}$ plasma concentration was of $1.28 \mathrm{mg} / \mathrm{L}$ at 21 -d-old and $1.45 \mathrm{mg} / \mathrm{L}$ at 70-d-old, which is considered normal for young pigs. 
Similar Zn plasma concentration were obtained among treatments, demonstrating the absence of influence of $\mathrm{Zn}$ sources supplemented in the maternal and nursery diets, respectively. Metzler-Zebeli., et al. [30] supplemented sow lactation diets with $240 \mathrm{mg} / \mathrm{kg}$ of a ZnAA or $120 \mathrm{mg} / \mathrm{kg} \mathrm{ZnO}$ and did not detect any differences in piglet $\mathrm{Zn}$ plasma concentration at birth $(0.57 \mathrm{mg} / \mathrm{L})$ or at weaning (1.05 mg/L). However, Caine., et al. [4] found higher $\mathrm{Zn}$ plasma concentration at birth and weaning $(0.63$ and $1.51 \mathrm{mg} / \mathrm{L}$, respectively) in the progeny of sows fed during the last trimester of gestation with $250 \mathrm{mg} / \mathrm{kg}$ of a ZnAA compared with ZnO. Wang., et al. [31] reported higher $\mathrm{Zn}$ plasma concentration in weaned piglets supplemented with $100 \mathrm{mg}$ of ZnGly (0.905 mg/L) per $\mathrm{kg}$ of diet compared with those not supplemented with $\mathrm{Zn}$; however, the highest concentration was determined when the diet was supplemented with $3.000 \mathrm{mg}$ of $\mathrm{ZnO}$ (1.230 mg/L) per kg of diet.

High Zn plasma concentration is commonly associated with increased synthesis of the protein metallothionein in the intestinal mucosa, which is vital for the uptake and storage of copper [35]. Although Zn plasma concentration was not different among treatments in the present study, at 21 days of age, the piglets from sows fed ZnAA showed higher bone mineral density $(\mathrm{P}<0.05)$ compared with those fed $\mathrm{ZnO}$, but not during the nursery period. Payne., et al. [23] reported that piglets fed $100 \mathrm{mg} / \mathrm{kg}$ ZnAA presented higher bone Zn concentration in compared with those fed $100 \mathrm{mg} / \mathrm{kg}$ ZnSO4 ( $<<0.05)$, but differences in bone strength.

It is established that trace minerals ( $\mathrm{Zn}, \mathrm{Fe}, \mathrm{Cu}, \mathrm{Mn}, \mathrm{Se}$ ) are essential for the maintenance of the immune status and resistance to diseases [36]. However, the Zn sources evaluated in the current study did not influence piglet immune status, as demonstrated by the lack of differences in antibody levels among treatments. Spears., et al. [37] did not find any immune response differences among piglets fed 50 or $150 \mathrm{mg} / \mathrm{kg}$ of $\mathrm{ZnSO} 4$ or zinc proteinate. The current $\mathrm{Zn}$ recommendations for nursery pigs are 80 - $100 \mathrm{mg}$ $\mathrm{Zn} / \mathrm{kg}$ diet [10,11] and $123 \mathrm{mg} \mathrm{Zn/kg} \mathrm{diet} \mathrm{[8].} \mathrm{According} \mathrm{to} \mathrm{van}$ Heugten., et al. [38], these concentrations supply the requirements for optimal performance and immune response, and the supplementation of inorganic sources by organic ones are not able to improve these characteristics. In contrast, Caine., et al. [39] reported that the progeny of sows fed a ZnAA from 80 days of gestation until farrowing presented better immune function within the first 24 hours after weaning, at 14 days of age.
The incidence of fecal score 2 (pasty feces) was influenced by $\mathrm{Zn}$ source supplementation both in the maternal and nursery diets $(\mathrm{P}<0.05)$. Piglets $\mathrm{ZnO}+\mathrm{ZnGly}$ group showed $28.2 \%$ the incidence of soft stools. The mechanisms by which $\mathrm{Zn}$ controls diarrhea are still not fully elucidated. According to Carlson., et al. [33], the beneficial effect of pharmacological doses of $\mathrm{Zn}$ is due to an increase in metallothionein levels (the protein that regulates the absorption of minerals in the intestinal mucosa), protein synthesis and cell proliferation, improving intestinal health status. Besides, Zn may inhibit the active transport of succinate into Escherichia coli cells, the activity of its oxidase system and respiratory chain, or even prevent its adhesion to the intestinal mucosa [40]; however, in the present study was used in according $\mathrm{Zn}$ recommendations for nursery.

The duodenal morphometry of 21-d-old piglets was not influenced by Zn sources supplemented in the maternal diets. However, at 70-d-old, lower villus height was measured in the duodenum piglets of the $\mathrm{ZnAA}+\mathrm{ZnGly}$ group, and lower crypt depth were measured in the $\mathrm{ZnO}+\mathrm{ZnAA}, \mathrm{ZnGly}+\mathrm{ZnAA}, \mathrm{ZnAA}+\mathrm{ZnAA}$, and ZnGly + ZnO groups. According to Nabuurs., et al. [41], villus height reaches the lowest values between 3 and 4 days after weaning and recover pre-weaning values between days 11 and 14 after weaning. The effects of post-weaning anorexia on digestive enzyme secretion and on the morphometry of the intestinal epithelium are multifactorial and include deprivation of luminal substrates for enterocyte growth and reduction of the expression of digestive organ growth factors, such as glucagon-like peptide 2, insulin-like growth factor I (IGF-I) [42], and cholecystokinin [43]. As a result, nutrient digestibility and absorption are impaired. Payne., et al. [23] reported that different dietary $\mathrm{Zn}$ sources $\left(100 \mathrm{mg} / \mathrm{kg} \mathrm{ZnSO}_{4}+100 \mathrm{mg} /\right.$ $\mathrm{kg} \mathrm{ZnAA}$ ) did not influence the duodenal morphometry of weaning piglets. Caine., et al. [4] also did not find any effect of the supplementation of $250 \mathrm{mg} / \mathrm{kg}$ of ZnAA sow diet on piglet duodenal villus height, crypt depth, or villus height to crypt depth ratio at weaning (14 days of age). Moreover, according to Metzler-Zebeli., et al. [30], the intestinal morphology of weaned piglets was not affected by the supplementation of $240 \mathrm{mg} / \mathrm{kg}$ of a ZnAA) in the diet of sows during lactation.

\section{Conclusion}

These data suggest that sows fed diets supplemented with 100 $\mathrm{mg} / \mathrm{kg} \mathrm{ZnO}$ during gestation may be able to increase total feed in- 
take of sow and piglets weaning weight and reduce body weight loss sow. However, in the nursery pig there seems to be very little difference among zinc source on intestinal morphometry, performance and zinc plasma concentration.

\section{Conflict of Interest}

We certify that there is no financial interest nor conflict of interest.

\section{Acknowledgement}

Claudia Cassimira Silva and Lúcio Francelino Araújo were supported by FAPESP receiving a scholarship (No. 2009/18542-9) and a grant (No. 2011/07578-2), respectively.

\section{Bibliography}

1. Yagüe A P. "Normatização do uso de minerais na alimentação suína”. Suínos and Cia 32 (20090:11-18.

2. Pinheiro SRF. "Uso de zinco na alimentação de leitões". Revista Eletrônica Nutritime 1 (2004): 157-163.

3. Shankar AH and Prasad AS. "Zinc and immune function: the biological basis of altered resistance to infection". The American Journal of Clinical Nutrition 68 (1998): 447S-463S.

4. Caine WR., et al. "Supplementation of diets for gestating sows with zinc amino acid complex and gastric intubation of suckling pigs with zinc-methionine on mineral status, intestinal morphology and bacterial translocation in lipopolysaccharide-challenged early-weaned pigs". Research in Veterinary Science 86 (2009): 453-462.

5. Mahan DC., et al. "Macro and mineral composition of fetal pigs and their accretion rates during fetal development". Journal Animal Science 87 (2009); 2823-2832.

6. Li C., et al. "Minerals and trace elements in human breast milk are associated with Guatemalan infant anthropometric outcomes within the first 6 months". The Journal of Nutrition 146 (2016): 2067-2074.

7. Richards MP. "Zinc, Copper and iron metabolism during porcine fetal development". Biological Trace Element Research 69 (1999): 27-44.

8. Rostagno HS., et al. "Tabelas brasileiras para aves e suínos: composição de alimentos e exigências nutricionais". Viçosa: Universidade Federal de Viçosa (2017): 488.
9. Schlegel P., et al. "Bioavailability of zinc sources and their interaction with phytates in broilers and piglets". Animal 7 (2013): 47-59.

10. NATIONAL RESEARCH COUNCIL. "Nutrient requirements of swine". 10th rev. ed. Washington, DC: National Academy Press (1998).

11. NATIONAL RESEARCH COUNCIL. "Nutrient requirements of swine". 11. ed. Washington, DC: National Academy (2012): 400.

12. Brugger D., et al. "Development of an experimental model to assess the bioavailability of zinc in practical piglet diets". Archives of Animal Nutrition 68: (2014) 73-92.

13. Hill GM., et al. "Comparison of organic and inorganic zinc sources to maximize growth and meet the zinc needs of the nursery pig". Journal of Animal Science 92 (2014): 1582-1594.

14. Condé MS., et al. "Minerais quelatados na nutrição de suínos". Revista Eletrônica Nutritime 11 (2014): 3547-3565.

15. Nitrayova, S. et al. "Bioavailability of zinc from different sources in pigs". Journal of Animal Science 90 (2012): 185-187.

16. Ma L., et al. "Effects of low-dose organic trace minerals on performance, mineral status, and fecal mineral excretion of sows". Asian-Autraliasian Journal of Animal Science 33 (2020): 132138.

17. AOAC. "Official Method of Analysis of the Association of Official Analytical Chemists". AOAC International, Arlington (1996).

18. Louzada MJQ., et al. "Densidade de peças ósseas de frangos. Estudo pela densitometria óptica radiográfica”. Veterinária $e$ Zootecnia 9 (1997): 95-109.

19. Pekas JC. "Morphometry of the intestine of the pig. I. A method for complete circumsection analysis". Digestive Diseases and Sciences 31 (1986): 79-89.

20. SAS. STATISTICAL ANALISYS SYSTEM. SAS: software. v. 9.3. Cary: SAS Institute (2010).

21. Yin J., et al. "Dietary supplementation with zinc oxide stimulates ghrelin secretion from the stomach of young pig". The Journal of Nutrition Biochesmistry 20 (2009): 783-790.

22. Wang M., et al. "Zinc in wheat grain, processing, and food". Frontiers in Nutrition (2020). 
23. Payne RL., et al. Growth and intestinal morphology of pigs from sows fed two zinc sources during gestation and lactation". Journal Animal Science 84 (2006): 2141-2149.

24. Zetzsche A., et al. "Influence of formula versus sow milk feeding on trace element status and expression of zinc-related genes in the jejunum, liver and pancreas of neonatal piglets". Archives of Animal Nutrition 69 (2015): 366-377.

25. Davin R., et al. "Zn status of sows and piglets as affected by diet and sow parity". Livestock Science 178 (2015): 337-344.

26. Grela ER., et al. "The influence of microbial phytase supplementation to diets with high or low native phytase activity on sow reproductive traits and composition of colostrum and milk". Journal of Animal Feed Science 19 (2010): 418-429.

27. Csapó J., et al. "Protein, fats, vitamin and mineral concentrations in porcine colostrum and milk from parturition to 60 days". International Dairy Journal 6 (1996): 881-902.

28. Hu P., et al. "Dynamic changes of fatty acids and minerals in sow milk during lactation". Journal of Animal Physiology and Animal Nutrition 103 (2018): 1-9.

29. Matte JJ., et al. "Maternal perinatal transfer of vitamins and trace elements from sows to piglets: more than an iron deficit?". Journées de la Recherche Porcine en France 46 (2014): 71-76.

30. Metzler-Zebeli BU., et al. "Supplementation of diets for lactating sows with zinc amino acid complex and gastric nutrimentintubation of suckling pigs with zinc methionine on mineral status, intestinal morphology and bacterial translocation in lipopolysaccharide-challenged weaned pigs". Journal of Animal Physiology and Animal Nutrition 94 (2010): 237-249.

31. Wang Y., et al. "Dietary Zinc Glycine Chelate on Growth Performance, Tissue Mineral Concentrations, and Serum Enzyme Activity in Weanling Piglets". Biological Trace Element Research 133 (2010): 325-334.

32. Case CL and Carlson MS. "Effect of feeding organic and inorganic sources of additional zinc on growth performance and zinc balance in nursery pigs". Journal Animal Science 80 (2002): 1917-1924.

33. Carlson MS., et al. "Early and traditionally weaned nursery pigs benefit from phase-feeding pharmacological concentrations of zinc oxide: effect on metallothionein and mineral concentrations". Journal of Animal Science 77 (1999): 1199-1207.
34. Kaneko JJ. "Clinical biochemistry of domestic animals". 4th ed. San Diego, CA: Academic Press (1989).

35. Carlson D., et al. "Assessment of zinc and copper status in weaned piglets in relation to dietary zinc and copper supply". Journal of Animal Physiology and Animal Nutrition 91 (2007): 19-28.

36. Dardenne M., et al. "Rationale for the mechanism of zinc interaction in the immune response". In: CUNNINGHAM-RUNDLES, S. (Ed.) Nutrient modulation: of the immune response. New York: Marcel Dekker Inc (1993): 501-509.

37. Spears JW., et al. "Effect of dietary zinc source and level on performance, zinc status and imune response of nursery pigs". In: NORTH CAROLINA WASTE MANAGEMENT SYMPOSIUM, North Carolina State University, Raleigh, USA, 1999. Proceedings. Raleigh (1999): 376-382.

38. Van Heugten E., et al. "Effects of organic forms of zinc on growth performance, tissue zinc distribution, and immune response of weanling pigs". Journal of Animal Science 81 (2003): 2063-2071.

39. Caine WR., et al. "Intestinal development of pigs from sows fed a zinc amino acid complex". In: PROCEEDINGS BANFF PORK SEMINAR, 2001, Canadá. Anais... Canadá 12.15 (2001).

40. Menin A., et al. "Avaliação in vitro do papel do zinco no mecanismo de adesão da Escherichia coli em suínos". Acta Scientiae Veterinariae 34 (2006): 149-152.

41. Nabuurs MJA., et al. "Villus height and crypt depth in weaned and unweaned pigs, reared under various circumstances in the Netherlands". Research in Veterinary Science 55 (1993): 78-84.

42. Vente-Spreeuwenberg, MAM and Beynen, AC. "Diet-mediated modulation of small intestinal integrity in weaned piglets". In: Pluske, J.R., Le Dividich, J., Verstegen, M.W.A. Weaning the Pig: Concepts and Consequences. Wageningen: Wageningen Academic Publisher (2003): 145-199.

43. Montagne L., et al. "Main intestinal markers associated with the changes in gut architecture and function in piglets after weaning". British Journal of Nutrition 97 (2007): 45-57.

\section{Volume 3 Issue 10 October 2021 (c) All rights are reserved by Lúcio Francelino Araújo., et al.}

